\title{
An "Eventful" History of Hind Swaraj: Gandhi between the Battle of Tsushima and the Union of South Africa
}

\author{
Jonathan Hyslop \\ Department of Sociology, University of Pretoria, South Africa
}

On July 1, 1909, Gandhi was on board the liner Kenil-worth Castle en route from Cape Town to Southampton. The prosperous Johan-nesburg lawyer had recently emerged as a noted figure in the politics of the British Empire, through his leadership of the satyagraha of Indian immigrants in the Transvaal. The union of the four self- governing British colonies in South Africa into a single state under white control was now under way and awaited ratification by the Westminster parliament. Gandhi's aim was to lobby the British authorities for the protection of the interests of the immigrant Indian population within this new order. On the voyage, he spent some time talking to fellow passenger John X. Merriman, the English- born, liberal political leader of the Cape Colony, who gave him a sympathetic hearing. But Merriman was losing his battle with Afrikaner General Louis Botha to become prime minister of the new state (Lewsen 1982: 300-301). And Merriman's Gladstonian worldview was in any case a thing of the past. The white men of South Africa had cut a deal among themselves to create a racially defined nation, and Herbert Asquith's Liberal government in Westminster, feeling guilty about the suffering of the Afrikaners in the Boer War and for the most part committed to defending the empire, wanted to allow them to implement it.

In London, during the evening of that day, an event occurred that was to be of pivotal importance in the writing of Gandhi's book Hind Swaraj. At the Imperial Institute in South Kensington, a reception was being held. It was attended by Sir William Curzon Wyllie, aide-de-camp to Sir John Morley, the reforming 
secretary of state for India. As Curzon Wyllie descended the steps on his way out, he was approached by a student wearing dark glasses and a blue turban, by the name of Madan Lal Dhingra. Dhingra pulled out a revolver and fired twice at Curzon Wyllie. Curzon Wyllie fell to the ground and Dhingra fired several more shots, killing him. Doctor Cowasji Lalcala attempted to grab Dhingra's arm and was instantly shot dead. On July 27 Dhingra's trial commenced. He was repentant about the killing of Lalcala but not about that of Curzon Wyllie. His statement at the trial was a patriotic declaration that impressed even the home secretary, Winston Churchill. Sentenced to death, Dhingra was hanged at Pentonville Prison on August 17 (Dhingra 2008; Herman 2008: 163-66).

By the time Gandhi arrived in London on July 10, the world of Indian nationalism was agog with the news. In the city, as around the world of the Indian diaspora and in the major centers of India itself, young, radical, educated Indians were electrified with excitement by Dhingra's deed. Militants were hailing it as a defining moment for India.

During the next four months in England, Gandhi was saddened by the widespread adulation of political violence in the pan-Indian political world and disillusioned by the polite but ultimately negative response by senior British officials to his entreaties regarding the situation of South African Indians. When, in November, during his return to South Africa on the Kildonan Castle, Gandhi sat down to write his Gujarati draft of Hind Swaraj, it was largely with the purpose of countering favorable interpretations of Dhingra's actions. He would instead, through the book, subtly seek to put forward his own political claims, based on the ideas developed in the peaceful militancy of the campaign in the Transvaal.

The ultimate success of Gandhi in dominating Indian nationalism has created something of an optical illusion in our view of that movement. It is popularly seen as essentially peaceful and tolerant, in the Gandhian mold (even though historians are aware of its frequent eruptions into violence, culminating in the partition catastrophe of 1947). But research over the past decade (Silvestri 2000; Price 2005; Manjapra 2006; Fischer-Tine 2007; Heehs 2010) has come to highlight the strength of violent revolutionary currents within Indian nationalism. It is arguable that between 1905 and 1915, the "terrorist" political trend was the dominant one, reaching a climax in the Ghadar movement's failed but impressive attempts, at the beginning of World War I, to return large groups of armed militants to India and to ferment revolt in the army. This makes it all the more remarkable that Gandhi was able to win political leadership by 1919. The publication of Hind Swaraj was a crucial moment in this story. It is best understood not as an abstract work of political philosophy but as a political intervention aimed at shaping the emerging 
culture of Indian nationalism in the specific context of the pre-First World War years. It was Gandhi's manifesto for an ideology of Indian nationalism, which he was to pursue over subsequent decades.

My argument in this article is that in Hind Swaraj Gandhi embarked on a symbolic reinterpretation of contemporary events, through which he was able to begin to shift the cultural structures of Indian politics. The genius of Hind Swaraj is that it performed this act of reinterpretation in a way that politically positioned Gandhi's ideas as the most radical and truly national of all political strategies while at the same time almost surreptitiously leaving the door open to pragmatic engagement with the colonial power.

Partha Chatterjee (2005: 100) in his seminal work on nationalism puts forward an incisive analysis of Hind Swaraj:

Gandhianism ... was an ideology conceived as an intervention in the elite-nationalist discourse of the time and was formed and shaped by the experiences of a specifically national movement. It is only in looking at it in that historical context that it is possible to understand the unique achievement of Gandhianism: its ability to open up the possibility for achieving perhaps the most important historical task for a national revolution in a country like India viz. the political appropriation of the subaltern classes by a bourgeoisie aspiring for hegemony within the nation state.

However, the present article points toward only a partial confirmation of Chatterjee's view. Certainly, the book was an intervention in "elite nationalist discourse." But it was only to a limited extent "formed and shaped by the experiences of a specifically national movement." This formulation seriously underestimates the transnational features of the work's origins. The Transvaal struggle and its unique conditions were crucial to the formation of the ideas put forward in the book. The historical context of the book was a global one, and questions such as the rise of Japanese power were central to its conception.

I do agree with Chatterjee that the Gandhian position, first formulated in Hind Swaraj, did provide elites with an ideology that allowed them to politically incorporate and mobilize the peasantry. But Gandhi could not have known in advance how effective it would be in that regard. Gandhi's immediate concerns at the time he wrote the book were to head off the political projects of his rivals and to claim leadership within the world of elite nationalists. Harald Fischer-Tine (2007) emphasizes the limits of elitist Indian exile politics in terms of its potential to mobilize people in India as an explanation of why terrorism declined precipitately as a force in Indian politics by the end of World War I. Yet Gandhi's long-term 
success in mass mobilization at home was based on his earlier work in advancing his views among the elite. Winning the battle for the minds of the existing political leadership, a campaign that he launched through Hind Swaraj, was the necessary preliminary to his later, broader achievement.

Underlying my argument is a concern to explore the relationship between event as occurrence and event as construction. ${ }^{1}$ I seek to understand both the concatenation of political events that made possible Hind Swaraj and the way that Gandhi, as a social actor, through the publication of Hind Swaraj, counterposed satyagraha to Dhingra's act as a future model for Indian nationalism, with enormous long-term consequences. Hind Swaraj is, to use William H. Sewell's (2005) term, an "eventful" work.

Reading Hind Swaraj as a contingent political intervention in the symbolic construction of events also helps us understand the startlingly extreme "antimodern" positions taken by Gandhi in the text, positions that he himself transgressed in practice. As Frederick Cooper (2005: 189-90) says, "The construction of colonizer and colonized is most valuable when read not against a generalized 'moder-

1. Here I want to draw on William H. Sewell's (2005) intriguing attempt at a historian's theorization of events. Based on the work of the anthropologist Marshall Sahlins, Sewell seeks to escape from the dilemmas posed by the conventional dualism of structure and action. Explicating Sahlins, Sewell (2005: 199) writes that events "can be distinguished from uneventful happenings only to the extent that they violate the expectations generated by cultural structures. The recognition of the event as event, therefore, presupposes structure. Moreover, what consequences events will have depends on how they are interpreted, and that interpretation can only be made within terms of the cultural structures in place." People use their existing cultural categories in being appropriated by, or appropriating, both expected and unexpected events. Sewell adds to Sahlin's theory the argument that structures are plural and that they are composed of both cultural schemas and material resources. The existence of multiple, competing structures helps generate the possibility of agency because of the chances it creates to move in the slippage between these structures. Structural change occurs when there is a shift in the pattern of both cultural dynamics and resources. Sewell also develops Sahlin's notion of a conjuncture of structures: a certain coming together of structures "that sets off a synergistic interaction between actors attempting to make structural sense of a highly volatile situation" (Sewell 2005: 204-5). Sewell highlights that events are sequences of occurrences that tend to occur in concentrated bursts. An initial rupture with existing practices touches off a chain of occurrences, which disrupt existing structures. What is very important for our purposes here is Sewell's observation that in revolutionary times, the dislocation of structures leads to a dramatic uncertainty, which can stimulate bursts of cultural creativity. In the absence of past certainties, we enter into a period when no one has an established schema of how to act, and we do not know what the consequences of particular actions will be. Crucially important too is Sewell's (2005: 245) observation that events are literally "significant," that they signify something new and surprising: "Symbolic interpretation is part and parcel of the historical event." In such times of extended structural dislocation, new possibilities for intervention open up (Sewell 2005: 251). But this situation does not last forever. In the long run, there will be a "rearticulation of structures." 
nity' but against the shifting needs and constraints facing colonial people and regimes in specific moments and the varying ability of colonial people to deflect and reinterpret all such projects, and the actual mechanisms of social construction." Cooper (2005: 147) suggests, rightly in my view, that the crucial question for historians to examine about the modern is how ideas about modernization were used politically in particular contexts. It is the "intensity of this historically rooted process of making claims and counterclaims" that should command our attention (Cooper 2005: 147). Hind Swaraj is an exercise in such claim making: it was directed toward clearing aside the pretensions of British paternalism, moderate practicality, and extremist radicalism, leaving Gandhi in sole possession of the field as the representative of Indian national political interests.

\section{Reinterpreting Political Violence and Modern Warfare}

Gandhi was both explicit and slightly disingenuous in his explanation of how he came to publish Hind Swaraj as a book. The original Gujarati text appeared in Gandhi's Durban-based newspaper, Indian Opinion, on December 11 and 18, 1909. An English translation was published as a book by his International Printing Press in the same city, in March 1910. In the preface to the English edition Gandhi (2006: 8) wrote, "Had I not known that there was a danger of the methods of violence becoming popular, even in South Africa, had I not been called upon by hundreds of my countrymen, and a few English friends to express my position on the nationalist movement in India, I would even have refrained for the sake of the struggle, from reducing my views to writing."

As we will see, countering the popularity of political violence among the political intelligentsia of India and its diaspora was indeed Gandhi's main concern. The decision to publish in English was a clear indication that Gandhi was targeting the educated Indian elite. Had he wanted to capture a broader audience he could have published in a range of indigenous languages, something that Indian Opinion regularly did.

But the internal evidence of the text suggests that Gandhi was less than forthright in his modest assertions that he had been pushed into publishing by admirers. Gandhi's sweeping dismissal of the existing Indian moderate and extremist leaders in the texts can only be read as the work of one who believed that the mantle of leadership was about to fall on himself. This view is supported by another aspect of Gandhi's account of the background to the publication of the book. Copies of Indian Opinion containing the Gujarati text were seized in Bombay on March 10, 1910, which Gandhi says hastened the decision to publish. According 
to Gandhi (2006: 7), he was concerned that to publish further material from the text in Indian Opinion would lead to the suppression of the paper in South Africa and therefore felt that a separate book was called for. This explanation is not very plausible, as Natal did not have a particularly tight censorship regime. As is often the case in Gandhi's practice, an apparently disinterested search for the truth just happened to coincide with his own claims to leadership.

It needs to be emphasized that Gandhi's primary target in the book was the terrorist movement. In the early sections of the book, the established moderate patriarchs of the Indian cause-Dadabhai Naoroji, Buddrudin Tyebji, and G. K. Gokhale, as well as their British supporters A. O. Hume and Sir William Wedderburn — are gracefully acknowledged, before being dismissed. Gandhi was well aware that the polite lobbying and Anglophilia of the previous generation had lost its appeal for the young Indians exemplified by his figure of the Reader. In the text Gandhi gives little attention to the moderates. It is apparent that to him the real contenders are the terrorists. He devotes the bulk of Hind Swaraj to challenging their political credentials. Indeed, even the sections of the text that are focused on a critique of Western civilization function indirectly to support Gandhi's attack on the terrorists, because for Gandhi the central failing of the terrorists is their desire to emulate modern political and military powers, rather than to revere the ancient civilization of India.

In a broader sense, though, Gandhi's work both responded to and coincided with a global structural dislocation of previously existing patterns of racial ideology, colonial politics, and great power relationships. This had been set in train by two interacting events that violated all expectations. The defeat of the Russian Navy by the Japanese at the Battle of Tsushima on May 27-28, 1905, stunned the world. After an epic journey from its European bases, via the Atlantic and the Indian oceans and the Strait of Malacca, the Russian fleet was destroyed as it entered the Sea of Japan. Only three out of thirty-eight Russian ships escaped sinking, capture, shipwreck, or internment, while the Japanese suffered minimal casualties (Pleshakov 2002). And in India, from 1903 to 1904, the partition of Bengal by Lord Curzon unleashed a mass protest movement, often focused on swadeshi, the promotion of local manufactures against imported products. There were supportive protests and boycotts throughout the major centers of the Raj.

Across Asia, radicalizing political elites interpreted the Japanese victory as a repudiation of European claims of racial superiority. The research of Cemil Aydin (2007) highlights the breadth of this impact in generating a sense of panAsian identification against the West. In India, especially, it gave a sharp stimulus to anticolonial politics. Sumit Sarkar (1994: 28-29) notes that in Bengal in this 
period the newspapers were "full of Japan, funds in aid of Japanese sick and wounded were collected through public entertainments ... and there were even cases of children being given nick-names after Japanese leaders." Awareness of the war was surely reinforced by its extensive photographic coverage in the print media, which, according to Marco Gerbig-Fabel (2008), tended to foreground modernist, technological images of the conflict.

Both the war and the antipartition movement shifted the structures of global politics. In the context of hard racial biologist ideologies and the vast expansion of European empires at the end of the nineteenth century, it had appeared that global inequalities along racial lines were immovable. Now the Japanese victory not only changed understandings of the global balance of military power but also encouraged Asian intellectuals to assert racial equality, engage in new forms of cultural delegitimization of imperial rule, and envisage and begin more militant political movements. In Bengal this reinforced and radicalized the existing agitation. At the turn of the century, the imperial order in India had appeared stable. Now it seemed threatened in a very direct way. Indian nationalism was strengthened by the overlap between the global destabilization of military power relations and the internal political upheavals within the Raj.

At a global level the rise of Japan created alarm in the metropolitan countries and settler states, among both elites and popular movements. Any sense of racial "superiority" as a guarantee against what was now being called the Yellow Peril was gone. Tsushima led directly to the founding of the Australian Navy. In 1908 President Theodore Roosevelt dispatched his "Great White Fleet" of battleships on a round-the-world cruise, implicitly as a warning to the new Asian power. In Australasia, southern Africa, Canada, and the United States, sentiment against Asian immigration heightened. The resulting exclusionary measures and antiAsian protests in turn bolstered Asian ideologies of national self-assertion (Lake and Reynolds 2008).

The most radical wing of Indian nationalism was represented by small terrorist groups that largely comprised young intellectuals and which emerged in India, mainly in Bengal, from around 1905. Although in organizational terms relatively ineffectual, they had a huge impact politically, both because their newspapers demanded outright independence, something even the extremist wing of Indian nationalism had hitherto been somewhat ambiguous about, and because they launched a number of violent attacks on British officials and on Indian collaborators. The terrorist groups were strongly inspired by the success of Japanese militarism. They saw terrorist violence as a first step to developing a level of military power that could drive out the British. The ruptures of the Japanese victory 
and the antipartition movement had thus touched off a chain of consequences in Indian politics. In 1907 the Indian Congress split at its annual conference between moderates and extremists. This was, then, a period of radical uncertainty leading to possibilities of cultural creativity.

What gave the Curzon Wyllie assassination its great potential for symbolic interpretation as a key event by the terrorists was its location in the imperial capital, the high status of the target, and the effectiveness with which it was carried out. Much as young radicals admired the terrorists in Bengal, the way that their campaign had unfolded was unimpressive. The terrorists had found it relatively easy to attack Indian policemen and informers but much more difficult to kill British officials. Moreover, their reputation was damaged by an attack in Muzaffarpur in April 1908 that accidentally killed two British civilian women instead of the intended target. Dhingra's act, by contrast, could be symbolically interpreted as a historic event, opening a period of successful armed struggle. Terrorist propagandists set out to make this argument. In Paris, the exile paper Bande Matram declared that "Dhingra behaved at each stage of his trial like a hero of ancient times. . . . In time to come, when the British Empire in India shall have been reduced to dust and ashes, Dhingra's monument will adorn the squares of our chief towns" (Brown 1975: 75).

Although Gandhi was well aware of the terrorist movement through his assiduous reading of the Indian press, his actual confrontation with it occurred through his meetings with the group based at India House, in Highgate, North London. Started as a base for Indian students by a well-off, radical former official, Shyamji Krishnavarma, India House attracted young men who were to include some of the most important radical figures in the history of Indian nationalism. Among them were the future pioneer of the Indian cause in the United States and Punjabi leader Lala Lajpat Rai; the future leader of the Ghadar revolutionary movement Har Dayal; and the future Indian Communist leader Virendranath Chattopadhyaya. Krishnavarma also established a paper, the Indian Sociologist, which combined enthusiasm for the theories of Herbert Spencer with advocacy of "extremist" politics. Gandhi had gone to India House on his 1906 visit to London and had already clashed with opinion there over the question of violence. In the interim, Krishnavarma had thought it prudent to relocate to Paris, and Vinayak Damodar Savarkar had emerged as the leading figure in India House. Savarkar was an ideologue of considerable ability, a translator of Giuseppe Mazzini and the author of the first Indian nationalist history of the 1857 rebellion. His speeches, calling on Hindu religious tradition and ideas derived from Mazzini's nationalism, radicalized the young men in his circle. He also instituted a program of training that included 
target practice at a shooting range in Tottenham Court Road. Dhingra was among the India House students, and it seems that Savarkar took the lead in instigating the attack on Curzon Wyllie. While he was in London, Gandhi engaged in debate with Savarkar and other India House luminaries. The outcome was chastening; it was clear that Gandhi was not finding much support from the young men around India House for his nonviolent politics (Brown 1975: 21 -84; Heehs 2000: 68 -95; Barooah 2004: 7-33; Owen 2007: 62-77).

Thus Hind Swaraj to a large extent mirrors Gandhi's debates with the London terrorists. Gandhi sought to debunk the idea of Dhingra's deed as a major event in the history of the Indian nation. His attack on the rising influence of the terrorists was constituted by his claims that their politics were un-Indian and reflected their adoption of the false modernism of the West. Gandhi (2006: 78-79) writes in Hind Swaraj that "those who rise to power by murder will certainly not make the nation happy. Those who believe that India has gained by Dhingra's act and such other acts in India make a serious mistake. Dhingra was a patriot but his love was blind. He gave his body in a wrong way; its ultimate result can only be mischievous." Gandhi acknowledges the sincerity of Dhingra's motivation but nevertheless explicitly characterizes him and, implicitly, Savarkar and the India House network as murderers. In claiming that even a successful rise of a violent movement would not make the nation "happy," Gandhi is basing himself on his understanding that violence begets violence. The allusion to Dhingra giving his body in the wrong way also highlights Gandhi's claim that physical and spiritual self-mastery is the core of any political self-rule.

Gandhi makes a substantial attempt to discredit the terrorists' admiration for Japan. Japan, for Gandhi, shows the dangers of emulating the West. In following the Japanese example, India would abandon its own genius, adopting instead a Western militarism. The Reader, representing the terrorist position, is set up as saying, "We will get [self-government] when we have arms and ammunition. ... As is Japan, so must India be. We must have our own navy, and we must have our own splendour, and then will India's voice ring through the world" (Gandhi 2006: 27 -28). The Editor, representing Gandhi's own view, then replies, "You have drawn well the picture. In effect it means this: we want English rule without the Englishman. You want the tiger's nature, but not the tiger: that is to say, you make India English, and when it becomes English, it will be called not Hindustan but Englistan. This is not the Swaraj that I want" (Gandhi 2006: 28). Thus Gandhi undercuts the claim of the terrorist to superpatriotism by suggesting that his embrace of violence is inherently antinational. Japan, by implication, has sacrificed its unique identity to a European model, and India will do the same if it fol- 
lows a similar route: "To arm India on a large scale is to Europeanise it" (Gandhi 2006: 77). This would involve the betrayal of Indian values, which still thrive: "Japan has become westernized, of China nothing can be said, but India is still somehow, sound at the foundation" (Gandhi 2006: 66).

Furthermore, Gandhi's advocacy of a village-based economy enables him to pose a utopian alternative to Japanese-style integration into the world market. Although the Japanese are apparently free, they are still economic clients of the British: "I remind you that it is the British flag which is waving in Japan, and not the Japanese. The English have a treaty with Japan for the sake of their commerce, and you will see that if they manage it, their commerce will greatly expand in the country" (Gandhi 2006: 41). Gandhi's attack on the terrorists also emerges through his celebration of the unique virtues of Indian civilization. In the aftermath of Tsushima, the terrorists had been greatly attracted by the ideal of pan-Asianism, specifically of a common interest between India and Japan. Gandhi's position undermines pan-Asianism through his clear support for a notion of Indian superiority over all other cultures, as he hails "the ancient civilization of India, which in my opinion, represents the best the world has ever seen" (Gandhi 2006: 7). The implication is that those Indians who see an equality among Asian civilizations are inherently unpatriotic, for they fail to recognize that Indian civilization surpasses all others. Such a position is remarkable given Gandhi's reputation as an internationalist; he is actually making a strong claim for Indian superiority.

\section{Reinterpreting the Transvaal Satyagraha}

In chapter 11 of Hind Swaraj, Gandhi puts forward the principles of satyagraha that he had developed in southern Africa as a future political direction for Indian nationalism. There is no explicit reference to the Transvaal campaign, but Gandhi's intended audience would undoubtedly have read the work with awareness of his role there. As Claude Markovits (2003) points out, something of a myth is in circulation that Gandhi was an obscure figure until his return to India in 1915, a notion created by Gandhi historians' relative lack of interest in his South African years. In reality, partly because of his own skills as a publicist (Young 2001: 329-31), Gandhi's activities in 1908 had received worldwide press coverage. For instance, the London Times covered the Johannesburg and Pretoria events of early 1908 in detail. In India, the campaign had been a litmus test of imperial actions in the eyes of activists. Even Aurobindo Ghosh, the most charismatic of the Bengali terrorist leaders, favorably compared Gandhi's organizational achievements 
to that of the swadeshi movement in India itself (Sarkar 1994: 77-78). The first Gandhi biography, a laudatory work by his close friend in Johannesburg the Reverend Joseph J. Doke, was published in 1909 and established some of the key narrative features of the Gandhi legend.

The absence of any specific mention of the Transvaal arises because Gandhi wanted to emphasize that the ideas he was advancing were the necessary, organic embodiment of Indian civilization as a whole. To have overtly punted the South African background to his program would have been to reveal that it was the outcome of contingent politics, atypical experiences, and eclectic intellectual influences. (The role of followers of the mystical sect of theosophy in Johannesburg, many of them Jewish, is an example of this last effect [Chatterjee 1992; Paxton 2006].) When asked by the Reader for historical evidence of the success of satyagraha, the Editor refers immediately, not to Gandhi's activities, but to the teachings of the revered medieval author Tulsidas. Gandhi (2006: 95) depicted satyagraha as a long-established Indian indigenous practice rather than his own invention:

In India, the nation at large has generally used passive resistance in all departments of life. We cease to co-operate with our rulers when they displease us. This is passive resistance.

I remember an instance when, in a small principality, the villagers were offended by some command issued by the prince. The former immediately began vacating the village. The prince became nervous, apologised to his subjects, and withdrew his command. Many such instances can be found in India.

Thus Gandhi was able to play a dual game: drawing on the prestige he had accrued through his role in South Africa and implicitly holding up his own leadership as a model, while eliding the thoroughly modern politics he was practicing with notions of historical continuity.

As well as outlining Gandhi's precepts, chapter 11 also displaces the terrorists' claim to heroism and masculinity, by suggesting that satyagraha requires much more courage and self-sacrifice than modern warfare does: "Wherein is courage required - in blowing others to pieces from behind a cannon or with a smiling face to approach the cannon and to be blown to pieces?" (Gandhi 2006: 93). Gandhi was determined to appropriate the discourse of soldierly virtue for the cause of nonviolence, by reversing the terrorist identification of violence with effective resistance.

The South African experience was also Gandhi's implicit model for another 
important aspect of his political ideology as presented in the book, the need for interfaith unity in the political struggle. Gandhi, a Hindu, had been brought to South Africa as a lawyer by Muslim merchants, and he had good relations with the Indian Muslims in the Transvaal and Natal. Most important, though, his closest allies in the Transvaal had been Muslims The initial campaign of 1908 had been organized by a committee based in the Hamidia Mosque in Johannesburg, and Gandhi had held his major meetings on the grounds surrounding the mosque (Swan 1985; Itzkin 2001). The common problems facing the Transvaal Indians had enabled Gandhi to mobilize them across the basis of religion, class, or regional origin. This effort was much more difficult in India itself, especially since many militant extremists identified as high-caste Hindus or Bengali particularists. The Reader shares the Hindu anti-Muslim chauvinism that was quite typical of admirers of the terrorists, asking, "Has the introduction of Mahomedanism not unmade the nation?" (Gandhi 2006: 52). To this, the Editor / Gandhi figure replies that

those who are conscious of the spirit of nationality do not interfere with one another's religion. If they do, they are not fit to be considered a nation. If the Hindus believe that India should be peopled only by Hindus they are living in a dreamland. The Hindus, the Mohomedans, the Parsees and the Christians who have made India their country are fellow countrymen, and they will have to live in unity if only for their own interest. In no part of the world are one nationality and one religion synonymous. (Gandhi 2006: $52-53)$

Because of his South African leadership of Muslims, Parsis, and people of low caste, Gandhi's advocacy of the possibility of national unity carried plausibility when he wrote that "if two brothers want to live in peace, is it possible for a third party to separate them? If they were to listen to evil counsels, we would consider them foolish. Similarly we Hindus and Mohammedans would have to blame our folly rather than the English, if we allowed them to put us asunder" (Gandhi 2006: 56). As Chatterjee (2005: 110) rightly observes, "Gandhianism provided for the first time in Indian politics an ideological basis for including the whole people within the political nation." It is important to realize, though, that this unitary idea was founded in the Transvaal practice of 1908-9. The concept was advanced in Hind Swaraj in explicit contrast to the elitism of the moderates and the Hindu chauvinism of the terrorists and extremists and was backed by the prestige of Gandhi's achievement in the Transvaal.

Gandhi's treatment of India's constitutional future heads off the challenge of the terrorists' call for total independence. At a fundamental level, Gandhi negates 
the importance of constitutional arrangements in general. The great task for Indians is to achieve self-mastery, in the mold of the satyagrahi, embracing poverty, chastity, and fearlessness, in order to defy unjust laws. In summing up the teaching of his book, Gandhi writes in the original Gujarati text that "one's rule over one's mind is real swaraj" (Gandhi 2006: 118n240; translation by Anthony J. Parel). There is here an element of ascetic withdrawal from the world that relativizes the importance of political arrangements.

Gandhi's appeal to authenticity is to some degree a tactic in his discursive struggle. Much recent scholarship has usefully drawn attention to the existence of multiple forms of modernity, and Gandhi is indeed a case in point; he created a new type of politics, very different from those that then prevailed in Europe. But Gandhi's own ideological claim was quite explicitly that he was not seeking a route to modernity different from that of the West but rather that he stood for the historical continuity of the Indian village and its values. He needed, then, to conceal that there was anything new about what he was doing and that he was reliant for his political campaigns on many of the innovations he denounced. His wholesale dismissal of modern forms of transport, technology, politics, medicine, education, and law is so sweeping as to take many readers aback. In fact, Gandhi in his own life did not follow through on this hostility to modern technologies and political techniques. While he was penning his denunciation of long-distance travel, the stokers of the Kildonan Castle were shoveling coal into the ship's boiler furnaces beneath his feet. The railways were a crucial means of transport in Gandhi's campaigning activities. His political use of the media relied on the printing press and the telegraph. Gandhi did in his later life occasionally make use of Western-style hospitals. Hind Swaraj was aimed precisely at the Indian elite produced by Western education. Despite Gandhi's smashing attack on the legal profession, both in South Africa and in the future in India, his movement made extensive use of legal tactics and compromises, and he continued to practice law until leaving South Africa in 1914. The function of the antimodernity of Hind Swaraj is largely one of political claim making. By launching such an absolute attack on modernity, Gandhi was able to position himself as more radical than the terrorists in rejecting the West and thus as a better representative of Indian authenticity.

\section{Reinterpreting Imperial Constitutionalism}

Gandhi's indication that the urging of his English friends had played a part in the publication of Hind Swaraj points us to another aspect of this elusive work. While 
succeeding in ideologically outflanking the extremists and terrorists through his indigenist claims to patriotism and radicalism, Gandhi nevertheless sends subtle signals in the direction of the reformers within the British establishment that he is a reasonable political interlocutor, in a way that the extremists would not be. He does so in three ways. First, he repositions India within current constitutional debate on the creation of self-governing states within the empire. Second, he indicates that he opposes racially based hostility to the British. And third, he folds his opposition to Indian terrorism into an implicit sympathy with a wider British fear of anarchist terrorism, showing that when it comes to dealing with political violence, he is of the party of order.

In doing so, Gandhi enters into a reinterpretation of the process of state reconstruction that was occurring within the empire. The second half of the nineteenth century and the start of the twentieth had seen the emergence of a constellation of new self-governing states in the white-settler-dominated parts of the empire. Canada (especially British Columbia), New Zealand, and, above all, Australia had strongly identified their democracy with their racial identity as white-settler states and the exclusion of Asian labor. These states could draw a sense of strength from the support of the right wing of the British Conservatives, who were advancing the idea of a superstate of the United Kingdom and the white-ruled colonies, based on common defense and imperial tariff protection, with the other colonies in a subordinate role. And of course Hind Swaraj was written in the context of the creation of a South African state on a nearly all-white franchise, which was actually inaugurated on May 31, 1910, just more than two months after the work went to press.

What Gandhi sought to do was to destabilize the connection between selfgovernment and white identity. Boldly, he reconfigured the change in South Africa as a sign of self-rule within the empire, rather than of the rise of racial polities, and inserted India, as a claimant to self-rule, into constitutional debate. In Hind Swaraj, the sensible Editor, although bracketing the question of whether Canadian-style self-government is desirable, finds it positive that the moderates have brought people together around "self-government, similar to what the Canadians and South Africans have" (Gandhi 2006: 27). Paradoxically, Gandhi actually uses the South African Union as a possible model for India, disrupting the discourse of a clear distinction between white-settler-ruled colonies and colonies directly administered from London. And in using the term home rule for the goal of the nationalist movement, Gandhi could only be read as referring to the example of the British Liberal program for self-government in Ireland. Irish home rule was once again on the political agenda in Britain, after a long break since William 
Ewart Gladstone's failed attempts to implement it late in the nineteenth century. It implied self-government within the British state, not any departure from the empire. And because color was not an issue in Ireland, as it was in the constitutional formation of the settler colonies, it could be taken as a constitutional model for India in a direct way.

Gandhi was confident in making openings toward British imperial reformists, because he understood both the fragility of colonial rule and the opportunities that the current reorganization and disarticulation of imperial political organization gave him for engaging in discussion on its structure. Cooper rightly identifies fragility as a crucial feature of imperial rule. Both anticolonial activists in Gandhi's day and Marxist and Foucauldian scholars of empire in the present have tended to attribute an overwhelming strength to colonialism. But as Cooper (2005: 157) points out, the most extreme acts of colonial violence "reflected the weakness of routinized administration and policing in colonial territories and the need to keep the costs of administration and discipline low." The imperial power was far from being in total control of India, and Gandhi was fully aware of this weakness. He wrote in Hind Swaraj that "the English have not taken India: we have given it to them. They are not in India because of their strength, but because we keep them" (Gandhi 2006: 39).

The empire as a whole, far from being a functional machine, was a complexly articulated set of differing interests and powers. Gandhi's effectiveness lay largely in his ability to engage in the game of what Cooper calls "thinking like an empire." Gandhi was a virtuoso in the political use of the international media (Young 2001: 329-31). In South Africa Gandhi had discovered the political possibilities inherent in combining a network of telegraphs and newspapers to generate a politics that was able to exploit the structural disarticulations within the empire. These existed at several levels. Within the administrative organization of the empire there were major difficulties. Control of India was divided between the viceroy's government in Calcutta and Simla and the secretary for India in the London cabinet. It is not difficult to see that this provided the opportunity for serious divisions as to the direction of government. The situation was further complicated by the fact that the India Office had a board, composed largely of old India hands, which had a constraining effect on an innovative secretary like Morley. With the radicalization of Indian politics, the viceroy and the secretary were anxious to conciliate Indian elites, and the result was the Minto-Morley reforms of 1909 (Gilmour 2005). However, all other colonies fell under the Colonial Office. By the turn of the century, the rising power and assertiveness of the white dominions meant that the Colonial Office was stuck between its fear of 
offending white colonial opinion and its desire not to surrender further authority to the colonists. The picture was further complicated by the tradition in the upper levels of the British judiciary of disapproving of explicitly racially based legislation, not a negligible factor when the Privy Council still remained the court of appeal for the whole empire. Thus Transvaal and Natal, where there was a significant Indian minority, posed a crucial dilemma. The viceroy's government, in particular, considered that it had a responsibility to Indians in the diaspora and was anxious to show Indian elites that they were defending the interests of abused Indian populations. But any interference with the role of the indentured laborers was likely to infuriate white colonial governments. In 1908 Gandhi had brilliantly manipulated the print media to generate a crisis among Pretoria, Calcutta, and London, which had placed him on the moral high ground. This situation exemplifies the process described by Cooper (2005: 189) whereby imperial rulers were constrained by the problems of ruling over populations in ways that "institutionalized both incorporation and differentiation" and by the "extent and unevenness of imperial space, which inevitably produced tensions among colonial elites and among different colonizing ideologies and interests."

Gandhi's politics in the time of Hind Swaraj was one of using these differences and unevennesses within the imperial order. The idea of total political independence for colonies was not a sine qua non of political radicalism before 1918. Gandhi did not explicitly call for formal independence for India until the end of the First World War. The identification of sovereignty with progressive causes was not as great as it was to become. Because a world of national sovereignties became the norm of late-twentieth-century world politics, there is a strong tendency to imagine that African and Asian politics in the pre-1914 world must have been framed in terms that resonated with the later attainment of such independence. But this was not necessarily the case. As Cooper (2005: 156-57) argues,

The dismemberment of the empires after World War I should not be projected backward. ... Empires did inspire loyalty and identification for a portion of their subjects, but more often they depended on contingent accommodation. They provoked opposition in the name of the solidaristic identification of conquered people and opposition based on seeking contingent accommodation with a different empire.

Hind Swaraj represents a brilliantly ambiguous position in which Gandhi moved away from his previous identification with the "contingent accommodation" with the British advocated by the moderates, while not accepting the form of solidaristic identification against them offered by the "extremists." Holding the door open 
to a politics of negotiation, Gandhi specifically repudiates the terrorists' rhetoric of driving the British into the sea. He acknowledges that "there have been lovers of liberty and members of Congress, both Indian and English" (Gandhi 2006: 14). He tells the reader that, anxious as they both are to attain swaraj, "to drive the English from India is a thought heard from many mouths, but it does not seem that many have questioned why it should be so" (Gandhi 2006: 26). He looks forward to an incorporation of those British who want to stay in India under self-rule, provided that they abandon the "modern civilization" to which they are attached: "It is not necessary for us to have as our goal the expulsion of the English. If they become Indianised, we can accommodate them" (Gandhi 2006: 73). While the prospect of becoming "Indianised" may not have appealed to many Britons, this was an important signal to sympathizers within the colonial power of Gandhi's political differentiation from the "extremist" position.

In Hind Swaraj Gandhi sets himself up as an opponent of violence in a way that appeals to British fears not just in regard to India but also in relation to internal political threats. His critique of the logic of political violence is not intended to be specific to the Indian cause; it is a philosophical attack on the use of violence in each and every case. One sign that Gandhi wishes to be seen as on the side of order lies in his characterization of the "physical force" dimension of British suffrage agitation before the Great Reform Act of 1832 (misdated 1833 by Gandhi). Gandhi (2006: 93) also uses the words physical force to refer, pejoratively, to the terrorists: "Physical force men are strangers to the courage that is requisite in a passive resister." The term physical force had been used throughout the nineteenth century in British political discourse to refer to violent opponents of the state such as the militant wing of the Chartists and the Irish Fenian movement. Gandhi (2006: 82) not only deplores violence but suggests that it led to a more general irresponsibility in British politics, in a way that would not have been out of place in a speech by a Tory member of Parliament: "We have before us in England the farce of everybody insisting on his rights and nobody thinking of his duty."

Such statements should be read in the context that one of the features of the era in Britain was fear by the establishment of violent anarchism. In the fifteen years before the publication of Hind Swaraj, European anarchists had assassinated an Austrian empress, a king of Italy, an American president, a French president, a Spanish prime minister, and a Portuguese king, among others. Fear of terror is not specific to our age. Joseph Conrad had published The Secret Agent, with its devastating portrait of London anarchists, in 1907. Because of Britain's tradition of political asylum, there was a major concentration of anarchists in London, and it has seriously been suggested that the only reason there were not more anarchist 
attacks in Britain in this period was that the refugees did not want to jeopardize their position. The fear of anarchism interacted with rightist hostility to Jewish immigration, and this conflict had been fueled by the murder of a Tottenham policeman by Latvian revolutionaries in January 1909 (Porter 1987).

Although few Indian terrorists were explicitly anarchist, the official mind tended to conflate anarchism and terrorism. Thus the Curzon Wyllie assassination generated considerable alarm within the British state, leading to the reorganization of Scotland Yard's special branch to include a wing focusing exclusively on Indian activists. Moreover, a minor thread of the Dhingra case must at the very least have reinforced the connection in the mind of officialdom between Indian terrorism and anarchism. In the wake of the Curzon Wyllie killing, the apolitical printer of Indian Sociologist, Arthur Horsely, was arrested, charged, and sentenced for producing seditious material. Guy Aldred, a twenty-two-year-old anarchist from Shepherd's Bush, then made a remarkable intervention in the case. As an act in defense of press freedom, Aldred took over the publication of the journal and was in turn charged and sentenced to a year's imprisonment. Aldred (1948) proclaimed his anarchist views from the dock. ${ }^{2}$ Gandhi had no sympathy with Aldred and expressed apparent satisfaction with the sentence in the columns of Indian Opinion (November 9, 1909).

For the politically astute British reader of Hind Swaraj, Gandhi would thus emerge as a potential Indian leader hostile to violence and anarchism and open to participation in the current framework of debate on the constitutional structure of the empire.

\section{Conclusion}

The expectations inherent in the moderate-dominated pre-1903 structure of Indian politics had been violated by the unexpected radicalization consequent on the partition of Bengal. The British had damaged the previously stable structure of their own rule, providing a space not only for mass mobilization but also for the emergence of the terrorist movement. The terrorists had sought to interpret the antipartition revolt as showing the way to a future of violent revolution. But this destabilization also interacted with the unsettling of the structures of racial ideology and military power represented by the Japanese victory and its consequences. This disruption in turn generated a new "conjunction of structures," opening up space for new kinds of political agency.

2. I am grateful to Lucien van der Walt for providing me with a copy of this rare text by Aldred. 
However, the triumph of the new Indian revolutionary politics was to be challenged - ultimately successfully — by Gandhi, through his own reinterpretation of the era. The uncertainty created by the disruption of existing structures was put to use by him to generate an alternative version of events. Gandhi rejected the terrorists' linkage of violence and popular sovereignty. Instead, he interpreted his age in a way that linked Indian identity and the practice of nonviolence. On this foundation he was, in the long run, to defeat the terrorists and bring about a rearticulation of the structures of Indian politics. Hind Swaraj set forth a cultural schema that was to be used by the Mahatma and his supporters to produce a shift in cultural dynamics and resources leading to the mobilization of Indian nationalism, from the beginning of the 1920s, under Gandhi's leadership.

Savarkar was to emerge late in Gandhi's life as the leader of the fundamentalist Hindu Mahasaba. When Gandhi was assassinated, Savarkar was tried as one of the conspirators. He was acquitted but remains widely suspected of complicity. Yet his triumph over his old India House adversary was a Pyrrhic one. In the course of its diffusion, Hind Swaraj provided the ideological platform for reversing, in large part, the judgments on history that the most militant Indian political class had been advancing in the 1903-15 period. Gandhi did succeed in delegitimizing the terrorist project. In the end the book itself became an important event of its own age.

\section{References}

Aldred, Guy. 1948. Rex v. Aldred: London trial, 1909, Indian sedition; Glasgow sedition trial, 1921. Glasgow: Strickland.

Aydin, Cemil. 2007. The politics of anti-Westernism in Asia: Visions of world order in pan-Islamic and pan-Asian thought. New York: Columbia University Press.

Barooah, Nirode K. 2004. Chatto: The life and times of an Indian anti-imperialist in Europe. New Delhi: Oxford University Press.

Brown, Emily C. 1975. Har Dayal: Hindu revolutionary and rationalist. New Delhi: Manohar.

Chatterjee, Margaret. 1992. Gandhi and his Jewish friends. Houndmills, U.K.: Macmillan.

Chatterjee, Partha. 2005. Nationalist thought in the colonial world: A derivative discourse. In The Partha Chatterjee Omnibus. New Delhi: Oxford University Press.

Cooper, Frederick. 2005. Colonialism in question: Theory, knowledge, history. Cambridge: Cambridge University Press. 
Dhingra, Leena. 2008. Madan Lal Dhingra. In Oxford dictionary of national biography. O-www.oxforddnb.com/.

Doke, Joseph J. 1909. M. K. Gandhi: An Indian patriot in South Africa. London: London Indian Chronicle.

Fischer-Tine, Harald. 2007. Indian nationalism and the "world forces": Transnational and diasporic dimensions of the Indian freedom movement on the eve of the First World War. Journal of Global History 2: 325-44.

Gandhi, Mohandas Karamchand. 2006. "Hind Swaraj" and other writings, edited by Anthony J. Parel. Cambridge: Cambridge University Press.

Gerbig-Fabel, Marco. 2008. Photographic artefacts of war, 1904-1905: The Russo-Japanese war as transnational media event. European Review of History-Revue Europeenne d'histoire 15: 629-42.

Gilmour, David. 2005. The ruling caste: Imperial lives in the Victorian Raj. London: John Murray.

Heehs, Peter. 2000. Nationalism, terrorism, communalism: Essays in modern Indian history. New Delhi: Oxford University Press.

- 2010. Revolutionary terrorism in British Bengal. In Terror and the postcolonial, edited by Elleke Boehmer and Stephen Morton. Chichester, U.K.: Wiley-Blackwell.

Herman, Arthur. 2008. Gandhi and Churchill. London: Arrow.

Itzkin, Eric. 2001. Johannesburg: Birthplace of satyagraha. Johannesburg: Witwatersrand University Press.

Lake, Marilyn, and Henry Reynolds. 2008. Drawing the global colour line: White men's countries and the international challenge of racial equality. Cambridge: Cambridge University Press.

Lewsen, Phyllis. 1982. John X. Merriman: Paradoxical South African statesman. Cape Town, South Africa: Ad Donker.

Manjapra, Kris K. 2006. The illusions of encounter: Muslim "minds" and Hindu revolutionaries in First World War Germany and after. Journal of Global History 1: $363-82$.

Markovits, Claude. 2003. The un-Gandhian Gandhi: The life and afterlife of the Mahatma. New Delhi: Permanent Black.

Owen, Nicholas. 2007. The British Left and India: Metropolitan anti-imperialism 1885 - 1947. Oxford: Oxford University Press.

Paxton, George. 2006. Sonja Schlesin: Gandhi's South African secretary. Glasgow: Pax Books.

Pleshakov, Constantin. 2002. The tsar's last armada: The epic voyage to the Battle of Tsushima. New York: Basic Books. 
Porter, Bernard. 1987. The origins of the vigilant state: London Metropolitan Police Special Branch before the First World War. London: Weidenfeld and Nicholson.

Price, Ruth. 2005. The lives of Agnes Smedley. New York: Oxford University Press.

Sarkar, Sumit. 1994. The swadeshi movement in Bengal, 1903-1908. New Delhi: People's Publishing House.

Sewell, William H. 2005. Logics of history: Social theory and social transformation. Chicago: University of Chicago Press.

Silvestri, Michael. 2000. The Sinn Fein of India: Indian nationalism and the policing of revolutionary terror in Bengal. Journal of British Studies 39: 454-86.

Swan, Maureen. 1985. Gandhi: The South African experience. Johannesburg: Ravan.

Young, Robert C. 2001. Postcolonialism: An historical introduction. Oxford, U.K.: Blackwell. 